\title{
ResearchGate
}

See discussions, stats, and author profiles for this publication at:

http://www.researchgate.net/publication/259433449

\section{The Fragility of Self-Respect:} Emotional Labour of Workfare Volunteering. Social Policy and Society, 12

ARTICLE in SOCIAL POLICY AND SOCIETY · JULY 2013

3 AUTHORS, INCLUDING:

\section{Thomas Kampen}

University of Humanistic Studies

8 PUBLICATIONS 4 CITATIONS

SEE PROFILE

\section{Evelien Tonkens}

University of Humanistic Studies

106 PUBLICATIONS 171 CITATIONS

SEE PROFILE 


\section{Social Policy and Society}

http://journals.cambridge.org/SPS

Additional services for Social Policy and Society:

Email alerts: $\underline{\text { Click here }}$

Subscriptions: Click here

Commercial reprints: Click here

Terms of use : $\underline{\text { Click here }}$

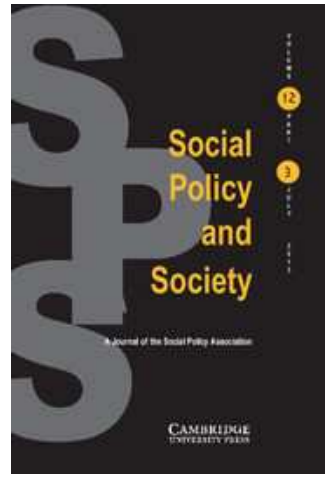

\section{The Fragility of Self-Respect: Emotional Labour of Workfare Volunteering}

Thomas Kampen, Judith Elshout and Evelien Tonkens

Social Policy and Society / Volume 12 / Issue 03 / July 2013, pp 427 - 438

DOI: 10.1017/S1474746413000067, Published online: 12 March 2013

Link to this article: http://journals.cambridge.org/abstract_S1474746413000067

How to cite this article:

Thomas Kampen, Judith Elshout and Evelien Tonkens (2013). The Fragility of Self-Respect:

Emotional Labour of Workfare Volunteering. Social Policy and Society, 12, pp 427-438 doi:10.1017/S1474746413000067

Request Permissions : $\underline{\text { Click here }}$ 


\title{
The Fragility of Self-Respect: Emotional Labour of Workfare Volunteering
}

\author{
Thomas Kampen*1, Judith Elshout ${ }^{* * 1}$ and Evelien Tonkens*** \\ *Amsterdam Institute for Social Science Research, University of Amsterdam \\ E-mail: t.g.kampen@uva.nl \\ **Amsterdam Institute for Social Science Research, University of Amsterdam \\ E-mail: j.a.g.elshout@uva.nl \\ ***Department of Sociology and Anthropology, University of Amsterdam \\ E-mail: e.h.tonkens@uva.nl
}

This article contributes to our empirical understanding of self-respect in rising meritocracies by focusing on the experiences of unemployed, low-skilled people recruited as workfare volunteers in the Netherlands. As many theorists have argued, the longterm unemployed struggle to maintain self-esteem. We found that workfare projects that introduce them to voluntary work can help them regain self-respect through four types of emotional labour: feeling respected through their newfound status, enjoying a craft, being able to perform in less stressful working environments, and taking pride in the meaning bestowed by voluntary work. But the emotional labour necessary to experience their situation more positively also increases the risk of experiencing negative emotions, thereby posing new threats to the fragile self-respect of unemployed citizens.

Keywords: Workfare, meritocracy, self-respect, emotional labour, volunteer work.

\section{Introduction}

'I have a lot of skills, but I am a nobody', laments Herman, an unemployed Dutchman. A dexterous forty-one-year-old, Herman performs all kinds of jobs in the construction industry. Still, he feels like a nobody because he works on a voluntary basis. Herman's story reveals what long-term unemployment can do to self-respect in a meritocratising society where both success and failure are seen as one's personal responsibility. In a meritocracy, group markers such as class, ethnicity and gender no longer determine socio-economic status. Citizens enjoy equal access to education while there is open competition for the positions that generate status and power (Swierstra and Tonkens, 2006, 2008).

We, of course, do not live in a full-fledged meritocracy. Class, ethnicity and gender still affect school performance and labour market position (see, for example, Boudon, 1974; Bourdieu and Passeron, 1977; Collins, 1979; Bourdieu, 1989; Ball et al., 1996; SCP, 1998: 603-5; Arrow et al., 2000; Sennett, 2003: 81; Dronkers, 2007; Van de Werfhorst and Hofstede, 2007). But over the last 150 years, we have witnessed the 'rise of meritocracy' (Young, 1958) to the point that the meritocratic ideal now virtually goes uncontested. Deeply embedded in policy discourse and public imagination, we attribute success to personal merit, and failure to the lack thereof. 
Numerous scholars have argued that 'the rise of meritocracy' damages the self-respect of people at 'the bottom' of society. Meritocracies add 'the insult of shame' (De Botton, 2004: 91) and fuel lack of respect for the 'losers' in society (Sennett, 2003). The British sociologist and politician Michael Young, who coined the term 'meritocracy', warned us half a century ago that meritocracy erodes the self-respect of those who end up on the lower rungs of the social ladder. Young agreed that a hierarchy based on achievement enhances equal opportunities and increases social mobility. But 'every selection of one is a rejection of many'; how to cope with this dark side of meritocracy is 'one of the great issues of modern society' (Young, 1958: 5-6).

Anthropologist Katherine Newman (1999) found that working in the least respected and lowest paid jobs in US society indeed undermines self-esteem. But few empirical studies exist to confirm or challenge her findings. This article contributes to our empirical understanding of self-respect in meritocracies by focusing on the emotional labour of the low-skilled, long-term unemployed doing volunteer work in projects designed to reintegrate them into the labour market. We expect self-respect to be a pertinent issue for these people. While workfare volunteering may open new avenues for renewed selfrespect and pride, it may also fuel feelings of marginality, shame and fear. This article thus asks: how do the long-term unemployed in rising meritocracies struggle with self-esteem? How does workfare volunteering affect their self-respect?

To answer these questions, we examined the experiences of the long-term unemployed in the Netherlands subject to workfare volunteering policies. Most of our respondents were on welfare and were therefore automatically subject to the Work and Assistance Act (WWB) introduced in 2004. The WWB expects low-skilled and longterm unemployed people who cannot easily find paid work to volunteer. The focus is on (voluntary) work rather than on acquiring new skills and qualifications (Van Berkel, 2006).

Policies to re-integrate welfare recipients into the labour market are part and parcel of the move towards an 'activating welfare state' (Goul Andersen et al., 2005; Serrano Pascual, 2007; Newman and Tonkens, 2011) or 'enabling state' (Gilbert and Gilbert, 1989; Gilbert, 2002). It includes a shift in discourse and practice from (collective and individual) rights to individual responsibilities, with governments no longer guaranteeing citizens financial security over their lifetimes but offering them the opportunity to work. Current policies are geared towards increasing economic activity; citizens must earn their rights while welfare recipients must fulfil the responsibility of volunteering to earn their benefits (some participants in citizen 'activation' projects are not personally subject to the WWB because their partners work or receive a benefit, and take part on a completely voluntary basis).

Research on citizen 'activation' policy has largely focused on the relationship between welfare recipients and the state (Soss, 1999; Korteweg, 2009; Soss et al., 2009; Dubois, 2010) and has tended to be critical of policies directing welfare recipients to the voluntary sector to enhance their employability (Bessant, 2000) or to empower them (Christensen, 2001). Critical research, often inspired by Foucault, has shown that such 'activation' policy is normalising and disciplining (Dean, 1995, 1999; Cruikshank, 1996, 1999; Rose, 1999; Walters, 2000; Marston et al., 2005), restricting individual freedom by weakening agency and narrowing the ideal of citizenship to that of the worker-citizen (Warburton and Smith, 2003; McDonald and Marston, 2005). Citizens become instruments of governance, instrumentalised and exploited to do unpaid work and to even feel 
happy about it: 'Power creeps under the skin of those who are governed to such a degree that they are even happy to conform' (Cruickshank, 1999: 10). While this critical reading is often based on the discourse analysis of policy texts, others have more recently turned to ethnographic methods (McDonald et al., 2003; McDonald and Marston, 2005; Lippert, 2005; Mitchell, 2006; Li, 2007) and 'bottom-up' analyses (Brady, 2011). The current article builds on this empirical turn. In contrast to most Foucauldian analyses, we do not a priori assume that 'workfare volunteering' is disciplining and exploitive, but empirically examine how it confines or liberates welfare recipients' actions, thoughts and emotions.

'The dramas of self-respect are played out in the domain of emotions' (Dillon, 1997: 226-7). To understand how people struggle to maintain their sense of self-worth in specific social situations, we make use of Hochschild's (1979) emotion management perspective as outlined in the introduction of this themed section.

Sennett (2003) argues that people can only respect themselves when they feel respected by others, Hampton (1997: 25-6) that social institutions play a key role in constructing our sense of self-worth. Margalit (1996) argues that a decent society is one in which institutions do not humiliate people, Rawls (1971) sees self-respect as a 'primary good' that social institutions and policies should be designed to support. Following Sennett, Hampton, Margalit and Rawls, we expect that the institutional context will play an important role in the emotional labour through which workfare volunteers develop, maintain and rebuild their self-respect.

\section{Sampling and respondents}

To examine the experiences of citizens subject to workfare volunteering programs, we held 150 in-depth interviews with 90 individuals in six Dutch cities. The interviews took place between 2009 and 2011; we tried to talk to all of our informants twice, with six months to a year in between, to observe how their self-respect changed over time. We were, however, unable to reach thirty of our informants after the first interview.

The six cities were selected from the thirty largest municipalities in the Netherlands. We sought maximum variation in the extent to which welfare recipients were obliged to participate in volunteer work and a balanced mix of 'citizen activation' projects that sought to empower welfare recipients or increase their employability. This resulted in four ideal-types of local 'citizen activation' policy: (1) sanctioning aimed at empowerment; (2) rewarding aimed at empowerment; (3) sanctioning aimed at employability; and (4) rewarding aimed at employability.

When the goal of volunteering was personal empowerment, projects aimed to enhance welfare recipients' control over their own lives by building up their self-confidence (Wieck, 1983; Rappaport, 1985). When enhancing employability was the main goal, volunteering was a means to acquire the skills needed to find and perform paid work. Welfare recipients were assigned to volunteer work when they were judged to be 'distanced from the labour market', as evidenced by lack of skills or weak employment history when policy primarily aimed to enhance employability, and weak self-image, problematic behaviour or social isolation when policies primarily stressed individual empowerment.

We sought to include in our sample a maximum spread in age, gender, ethnicity and in type of volunteer sector (neighbourhood: twenty-three; cultural: ten; educational: twenty-two; advocacy: nineteen; care: sixteen). Most respondents depended on welfare; a minority (mostly women) lived on their partner's income (nineteen out of ninety). We 
depended on the willingness of municipalities and respondents to participate in our research. We tried to contact 324 people: 181 did not answer the phone or the letter we sent; fifty-three were unwilling to participate, mainly due to lack of interest or research fatigue. We held in-depth semi-structured interviews with the remaining ninety individuals. All interviews were transcribed from audio files and analysed with the qualitative data software program Atlas.ti. Below we present our key empirical findings through the discussion of several exemplary cases. The names of our informants are fictitious.

\section{Being made to feel like a nobody}

The great majority of our respondents struggled with their self-esteem. Many reported that being unemployed made others view them as people who do not contribute to society. This perception of themselves, through the eyes of others, led many respondents to see themselves as 'a nobody', 'a failure', 'incapable' or even 'a bad person'. Wesley, a twentynine year-old who suffers from a psychiatric illness, was 'ashamed' of being unemployed: 'I am not capable of doing anything now.' Ayse, a forty-year-old Turkish-Dutch single mother of two, felt 'hopeless' and 'without capabilities' after she lost her job due to physical illness: 'When you suddenly fall, you are a nobody.' Feelings of 'incapacity' and 'inferiority' often went hand in hand with lack of educational attainment: 'even for stocking shelves in a supermarket you need a diploma'.

Being dependent on welfare made our respondents keenly aware of the perceptions of others. Remco, aged forty-one, feared that 'some people think I want to live on benefits, that I do not want to work'. The long-term unemployed often feel looked down upon by working people. Asked about his role in society, Remco answered: 'Nothing. I am nothing. From the Left to Right I get no respect. Totally nothing.' Fuller (2003) writes that people on the lower rungs of society suffer from indignity, humiliation and patronising behaviour. Our respondents confirmed this image. According to Fuller, dignity, which for him equals self-respect, is often defined by its absence. Being ignored, or the feeling of being ignored, is a form of insult and a result of 'rankism' (2003: 5). Almost all of our respondents were repeatedly rejected by potential employers. Nor did they feel that they were taken seriously by welfare officials. Herman felt like they looked down on him: 'For some organisations you are just a number. People do not listen.'

Repeatedly being rejected by employers, being seen as parasites in society and feeling inferior to employed citizens, all fuel feelings of worthlessness. We can safely conclude that long-term unemployment, dependence on welfare and interactions with welfare officials and employers undermine self-respect. The next sections present the core of our analysis: four types of emotional labour through which workfare volunteers strengthen their self-respect, and how this restored self-respect can be threatened again.

\section{Becoming a somebody}

Respect through status

Workfare projects can offer their participants a new role and status in society: that of volunteer in, for example, a museum or sports club. Volunteering can sometimes provide respectable labels such as 'teacher' (of the Dutch language in community centres) or 'coach' (who helps other neighbourhood residents with, for example, administration or 
housekeeping). Respondents in all volunteer sectors found their new roles to be important sources of social status.

In their new capacity as volunteers, the long-term unemployed can become known in their neighbourhoods, be taken more seriously and feel respected. Like many others, Ayse had felt anonymous when she lived on welfare. 'But now I can say "I am a coach".' A new title can make volunteers feel as though they are 'someone' again, 'part of something bigger'. Ayse's self-confidence rose as people came to know her as a coach, reinforced by the nameplate she received for her door engraved with her name and title. Workfare volunteers also felt that they were taken more seriously by authority figures. Ayse experienced this when she visited the doctor in her role as a coach to help a neighbour with the Dutch translation, an experience that bolstered her self-respect. Recognition comes with the new role and its associated status. It happens quite smoothly and requires little emotional labour.

We found earning respect through newfound status to be more common in rewarding policy regimes. We assume this is the case because compulsion runs the risk of undermining the respect workfare volunteers earn through their new roles. Those obliged to participate felt more often that they were not seen as 'real' volunteers.

This path to self-respect follows the meritocratic logic: status is based on personal merit. Like everyone else, one becomes a somebody by having a role reflected in a job title. It may not be paid, but otherwise it is a real job. Unsurprisingly, we observed this type of emotional labour most often in policy contexts that seek to make individuals more employable again. The three remaining types of emotional labour fit less easily with how meritocracy assigns value and worth in society.

\section{Enjoying a craft}

Framing volunteering as craftsmanship can preserve or generate self-respect. This most often occurs among workfare volunteers performing tasks that can be described as technical or creative, performed in their immediate neighbourhoods, and within the advocacy, educational and cultural sectors. Sennett (2003) argues that doing or creating something with passion and dedication (like learning to play a musical instrument) and making progress at it contributes to self-respect. Mastering a craft, in contrast to acquiring a new role and status, does not depend on the esteem and praise of others. Workfare volunteers who enjoy a craft focus on the task and the attendant sense of accomplishment; the meaning of their work to others is less important.

Volunteering offers workfare volunteers the possibility to 'become more skilled'. It is precisely what Sennett calls 'exploring how to do something well' and 'getting better at it' that allows the long-term unemployed to overcome feelings of uselessness. Michel found self-respect by volunteering for an organisation that works against the trafficking of women, searching the internet for information useful to the victims' lawyers. His efforts give him great satisfaction: 'Because of a certain talent that I have, I find the most obscure websites by clicking from link to link which generates a lot of information.' Remarkably, Michel emphasises that he 'is not looking for gratitude'. He apparently does not need recognition from the outside world to respect himself: 'I just want to get better at finding incriminating evidence of trafficking.' Remco (age forty-one), whose aim is to become faster and faster at fixing computers for people in his neighbourhood, proudly 
states: 'There is not one computer that has left the building unrepaired.' Regaining selfrespect apparently does not require the respect of others; finding obscure websites, fixing computers and creating works of art, as we observed in other cases, is fulfilling in itself.

The framing of volunteering as craftsmanship is easier when policy aims to further the long-term unemployed individual's empowerment rather than employability. Empowerment being the goal provides them with reasons to keep doing what they are doing without worrying about the profitability of their activities in the short-run. Whether policy is rewarding or sanctioning made no difference. We assume that this is so because by framing volunteer work as a craft, self-respect becomes less vulnerable to the (mis)recognition of the outside world through sanctions or rewards.

\section{Relaxing in respite}

Volunteering can restore self-respect by providing respite from competition, offering the long-term unemployed a relaxed atmosphere they would not find in a paid job. This type of emotional labour was most common among workfare volunteers engaged in outdoor and sports activities, in the educational and care sectors and in tasks performed in the immediate neighbourhood. They can do things at their own pace in contrast to the labour market where 'everything needs to happen quickly'. This is often helpful for individuals who suffer from or run the risk of physical or mental problems.

Paul, for example, is manic-depressive and thinks that finding a job will make him 'manic again': 'I am a little frightened to get steady work. In a volunteer job this pressure is absent.' Janice (age forty-one) suffers from a borderline personality disorder and has never held down a paid job. She is delighted with the opportunity to volunteer as it reduces the pressure of the outside world: 'They just take into account what you cannot do. That makes it less scary.'

Unlike paid employment, our respondents argued, volunteering allows one to make mistakes or decline difficult tasks. The peace this brings is a condition for regaining selfrespect. Bart (age fifty-five) works as a volunteer at an elementary school and thinks he would not succeed in a paid job because of 'all the extra pressure'. 'Then I get health issues, and I do not want that anymore.' So he sets limits on what he does as a volunteer: 'Before we took turns in taking minutes, but I found out that I really can't take minutes properly so I decline to do so. After all I am a volunteer.'

This type of emotional labour works best when policy is aimed at empowerment. Declining tasks of course does little to improve one's employability; it does, however, increase one's feeling of being in control. Furthermore, the goal of empowerment is geared to self-development, while the goal of employability is geared to developing skills for the labour market. While one would expect the compulsory nature of workfare voluntarism to negatively affect the peace people experience as volunteers, the opposite seems to be the case. The more people felt obliged to volunteer, the more they felt the decision to opt out of competition was made for them, instead of having to make it themselves.

\section{Pride in meaning}

Framing volunteer work as more meaningful than paid work is the fourth way to restore self-respect. This route to self-respect was most often seen among workfare volunteers in 
the care and cultural sectors. Thinking that they are pursuing more meaningful work than regularly employed persons often enables workfare volunteers to feel 'happy' and 'proud' about volunteering. But this path requires significant emotional labour. Through the moral framing rule that it is superior to be part of something meaningful or to mean something to others, they draw a line between the meaning of their activities and 'normal' jobs. They prefer meaning to materialism, contributing to an important cause to competing in a shallow rat race.

Volunteers who had previously been paid employees often contrast their meaningful volunteering to the shallow life they lived before. They often recount feelings of anger and disappointment in their previous jobs to legitimise feeling good about the alternative route they now follow. Eddy told us: 'I made a lot of money, but I always went to work with a grumpy face. They shouted, and I got very irritated.' After he resigned, Eddy began participating in a volunteer program as a buddy for a former drug addict. He recollects: 'If you had asked me at that time what I was proud of, I would have answered "my apartment, my job, how far I got in business". But now, yes, I am proud of being a buddy. That's what really makes me happy.' Eddy applies a historical framing rule: compared to earlier jobs, this one (which may be lower in status and payment) is superior because it is more meaningful.

These volunteers draw a clear line between their activities and less meaningful paid jobs. A drug addict since age twenty-one, Ray (now fifty-two) has never had a 'real job'. For three years he worked as a volunteer at a thrift store but then switched to a day care centre for the elderly, where he realised: ' $I$ ' $m$ a helpful person. It is just very important. More important than the thrift store.' Ray contrasts the meaningful work in the day care centre with the shallow materialism that he suspects drives the thrift store owner: 'That guy makes 90,000 Euros gross per year. For a social institution! You never see him. It's not kosher.' Nuraya (age twenty-eight), a Turkish-Dutch woman who just began volunteering at a horse riding school for mentally disabled children, values the purity of being in touch with nature, the horses and children. She talks about her activities as something that 'really matters' and 'something more real than a desk job'.

A rewarding policy regime aimed at empowerment is best suited to allow workfare volunteers to frame their activities as meaningful; the assignment to become more employable contradicts their idea of the deeper meaning of volunteer work. The empowerment logic of taking control of one's life is more in line with departing from the shallow materialism of paid work. While one might expect the aversion of materialism to sit uneasily with the rewarding policy context, small amounts of money are often perceived as recognition of their efforts. Distancing themselves from meaningless paid work seems harder in compulsory settings as these conflict with the volunteers' belief that they decided to opt out of competition themselves.

\section{The fragility of self-respect}

For those who criticise workfare policies from a governmentality perspective, both the positive and negative emotions recounted above confirm their argument that welfare recipients are disciplined and not free. The criticism is implicitly based on a notion of negative freedom, the freedom not to be bothered. Our respondents, however, seemed to care more about the positive freedom of creating or achieving something. This is not to say that they have entered through the gates of heaven by volunteering. Nevertheless, it is 
not the lack of negative freedom that disturbs them, but the lack of positive freedom that limits or threatens their recently regained self-respect.

First, when self-respect is bolstered by a rise in status, requests to perform tasks that do not confirm the new status can be experienced as attacks on status and self-respect. The request to clean toilets is a recurring example of such a status-undermining request, one that led Nuraya to quit her volunteer work at the stables. 'I was hired to supervise mentally disabled children. It is part of the job to pick up some horse turd now and then, but cleaning toilets is not.' She draws the line here because cleaning toilets symbolises low status. She is a volunteer, not a low-skilled employee. She emphasises that it was not the handling of excrement as such that made her quit. The issue is the symbolic meaning attached to the excrement: horse turd is respectable because it is part of her new status as a horse riding coach for children; handling human excrement stands for being underestimated and despised as a stupid, low-skilled immigrant. She suspects that her superiors think: as a Turkish-Dutch woman, 'Why would you want to work with horses? Why don't you just clean the toilet?' She feels disrespected and humiliated, which in turn threatens her self-respect.

Threats on the road to positive freedom also loom when volunteers frame their work as mastering a craft. Although framing volunteering as craftsmanship can initially challenge the idea that mainly education and a (good) job give access to self-respect, volunteers' self-respect is threatened when they reach the limits of their expertise and their demand for training and education to develop their skills gets zero petition. Michel: 'I told my supervisors: "If you had given me a course for a few weeks, then I would have learned it well".' Michel's disappointment reveals the limits of craftsmanship's contribution to self-respect. Moreover, when volunteers reach the point of mastering a craft, they want to take it to a higher level by getting proper education and training and eventually a proper paid job. If this fails, volunteers feel disrespected and end up disappointed.

The third route to gain self-respect, relaxing in respite, is threatened when the pressures of work are passed on from paid co-workers to volunteers. As volunteers often have difficulties defending their boundaries, this pressure undermines their emotion management. Jack recounts how he took over his (paid) superior's work at the computer centre when the superior called in sick: 'I looked after the computer centre for a whole week. That gave me a lot of stress!' Jack condemns the irresponsibility of his boss with a moral framing rule: if you are paid, you should feel responsible. 'This is a paid job. If he can't handle it, that should have consequences. Any other boss would have fired him a long time ago.' But this framing rule comes back to haunt Jack as he applies it to his own situation.

Volunteers working with paid colleagues may set high standards for their co-workers, thereby raising the bar for retaining self-respect when taking over tasks from paid coworkers. Having criticised colleagues using these standards, they must now live up to them. This tends to be detrimental to the relaxed atmosphere that was a prerequisite for their self-respect.

The fourth type of emotional labour, framing volunteer work as more meaningful than regular employment, is not free from threats to self-respect either. Volunteers who adopt this strategy are constantly alert for misrecognition of the meaning they ascribe to their work. This sensitivity easily surfaces when workfare volunteers are requested to perform tasks that they deem meaningless such as, once again, cleaning toilets. This time cleaning toilets contradicts the idea of living a meaningful life: they entered volunteering 
to do something more meaningful than that. For William, volunteering at the museum, to help 'guard our national history' thereby 'being part of something bigger', made his life meaningful. When his manager asked him to help out for a few months by cleaning the toilets, William first accepted because helping others is, for him, still part of something bigger and therefore still meaningful. But after eighteen months, it must be admitted that cleaning toilets has become a regular activity devoid of deeper meaning: 'I lend him a hand and then after eighteen months, if you are still in that same f..., ahem, still have the same job, I become angry.' When cleaning toilets becomes part of the job description, working at the museum is no longer more meaningful than a regular job. With his selfrespect damaged, William leaves and heads back to the welfare office where they try to help him find a new (volunteer) job.

\section{Conclusion}

As numerous theorists have assumed, we found that the long-term unemployed participants of workfare volunteering projects struggle to maintain their self-respect, continually threatened by their perceptions of others as well as of themselves. Although workfare projects that introduce them to voluntary work can support them in regaining their self-respect, they also create new threats.

Authors who consider 'activation' policies to be merely disciplining, serving only to restrict negative freedom and agency, overlook their complex emotional meaning. Workfare volunteering can contribute to a type of freedom ignored by most critical accounts: the (positive) freedom to live a meaningful and respectable life. But in a rising meritocracy, this freedom is limited and continually under threat.

We found four types of emotional labour through which workfare volunteers regain their self-respect. The first, respect through status, is in line with the meritocratic logic; it is the only type of emotional labour that works when the goal of policy is to enhance employability. The three other types are more critical of the ways in which meritocracy assigns value and worth. The second type of emotional labour, framing volunteering as craftsmanship, is critical of the (supposed) assault on skill and quality in meritocratic competition. The third, framing volunteering as more relaxed, is contrasted to the unnerving and stressful atmosphere that poisons the labour market rat race. This is the only type of emotional labour that thrives in a sanctioning policy regime since it yields more peace to have the decision to opt out of competition made for you than to make it yourself. The fourth type of emotional labour frames volunteering as more meaningful, important and socially valuable than the shallowness of paid work with its narrow focus on material reward.

Although all four types of emotional labour to regain self-respect can be effective, selfrespect for the long-term unemployed remains fragile. All paths contain new threats. First, to regain a role and status is helpful, but also vulnerable since in this logic, volunteering is still 'less': it cannot compete with the status one gets from a paid job. The second type of emotional labour, volunteering as a craft, can be hard to maintain over the long run. To become really good at something, chances are that sooner or later one needs more education, which is virtually excluded from workfare projects. If one nevertheless manages to become truly skilled, it is harder to accept lack of payment. Sooner or later the meritocratic logic re-surfaces: true merit should be rewarded. This finding partly contradicts Sennett's claim about the relationship between craftsmanship and self-respect. 
Learning a craft promotes self-respect through the feeling of being good at something. But craftsmanship does not suffice over time if it is not supported by training or a regular (paid) position. Craftsmanship can indeed be a solution to the 'social problem' of the 'scarcity of respect' (Sennett, 2003: 21) in our meritocratising society, but only if it is supported by a salary, the dominant and hard to surpass recognition of true merit.

The third type of emotional labour, framing volunteering as more relaxed, requires drawing a firm line between one's volunteering and pressure emanating from colleagues. With the fourth type, framing volunteering as meaningful work, a great deal of emotional management is necessary. Volunteers contrast their unpaid work with the shallow errands of bosses and colleagues, hardly a sound basis for fruitful relationships at work.

In the final analysis, volunteers who struggle to experience their situations more positively also increase the risk of experiencing negative emotions when their framing and feeling rules are challenged by relevant others, including friends, colleagues or bosses. Challenging the meritocratic logic through volunteering demands emotional labour. Volunteering can support individuals on the difficult road to regaining self-respect, but only so far. In a meritocratising society, self-respect remains fragile.

\section{Acknowledgements}

We would like to thank David Hymans for his patient and excellent editing.

\section{Note}

1 The joint first authors Thomas Kampen and Judith Elshout contributed equally to the article.

\section{References}

Arrow, K., Bowles, S. and Durlauf, S. (2000) Meritocracy and Economic Inequality, Princeton, NJ: Princeton University Press.

Ball, S. J., Bowe, R. and Gewirtz, S. (1996) 'School choice, social class and distinction: the realization of social advantage in education', Journal of Educational Policy, 11, 1, 89-112.

Bessant, J. (2000) 'Regulating the unemployed: Australia's work-for-the-dole scheme', Journal of Australian Studies, 24, 64, 75-84.

Boudon, R. (1974) Education, Opportunity and Social Inequality: Changing Prospects in Western Society, Paris: Armand Collin.

Bourdieu, P. (1989) 'Economisch kapitaal, cultureel kapitaal, sociaal kapitaal', in D. Pels (ed.), Pierre Bourdieu, opstellen over smaak, habitus en het veldbegrip, Amsterdam: Van Gennep, pp. 120-41.

Bourdieu, P. and Passeron, J. C. (1977) Reproduction in Education, Society and Culture, London: Sage

Brady, M. (2011) 'Researching governmentalities through ethnography: the case of Australian welfare reforms and programs for single parents', Critical Policy Studies, 5, 3, 264-82.

Christensen, E. (2001) 'The rhetoric of "rights and obligations" in "workfare" and "citizens' income": paradigms/discourses in Denmark in a labour history perspective', working paper, Aalborg University, Aalborg.

Collins, R. (1979) The Credential Society: A Historical Sociology of Education and Stratification, New York: Academic Press.

Cruikshank, B. (1996) 'Revolution within: self-government and self-esteem', in A. Barry, T. Osborne and N. Rose (eds.), Foucault and Political Reason: Liberalism, Neo-Liberalism and Rationalities of Government, Chicago: University of Chicago Press, pp. 231-51.

Cruikshank, B. (1999) The Will to Empower: Democratic Citizens and Other Subjects, Ithaca: Cornell University Press. 
Dean, M. (1995) 'Governing the unemployed self in an active society', Economy and Society, 24, 4, 559-83.

Dean, M. (1999) Governmentality: Power and Rule in Modern Society, London: Sage.

De Botton, A. (2004) Status Anxiety, London: Hamish Hamilton.

Dillon, R. S. (1997) 'Self-respect: moral, emotional, political', Ethics, 107, 2, 226-49.

Dronkers, J. (2007) Ruggengraat van ongelijkheid: beperkingen en mogelijkheden om ongelijke onderwijskansen te veranderen, Amsterdam: Mets and Schilt/Wiardi Beckman Stichting.

Dubois, V. (2010) The Bureaucrat and the Poor: Encounters in French Welfare Offices, Farnham: Ashgate.

Fuller, R. W. (2003) Somebodies and Nobodies: Overcoming the Abuse of Rank, Gabriola Island: New Societies Publishers.

Gilbert, N. (2002) Transformation of the Welfare State: The Silent Surrender of Public Responsibility, Oxford: Oxford University Press.

Gilbert, N. and Gilbert, B. (1989) The Enabling State: Modern Welfare Capitalism in America, Oxford: Oxford University Press.

Goul Andersen, J., Guillemard, A. M., Jensen, P. H. and Pfau Effinger, B. (eds.) (2005) The Changing Face of Welfare: Consequences and Outcomes from a Citizenship Perspective, Bristol: The Policy Press.

Hampton, J. (1997) 'The wisdom of the egoist: the moral and political implications of valuing the self', Social Philosophy and Policy, 14, 1, 21-51.

Hochschild, A. R. (1979) 'Emotion work, feeling rules, and social structure', American Journal of Sociology, $85,3,551-75$.

Korteweg, A. C. (2009) 'The politics of subject formation: welfare-reliant women's response to welfare reform in the United States and the Netherlands', in G. Marston and C. McDonald (eds.), Analysing Social Policy: A Governmental Approach, Cheltenham: Edward Elgar, pp. 107-26.

Li, T. (2007) The Will to Improve: Governmentality, Development and the Practice of Politics, Durham and London: Duke University Press.

Lippert, R. K. (2005) Sanctuary, Sovereignty, Sacrifice: Canadian Sanctuary Incidents, Power, and Law, Vancouver: UBC Press.

Margalit, A. (1996) The Decent Society, Cambridge, MA: Harvard University Press.

Marston, G., Larson, J. E. and McDonald, C. (2005) 'The active subjects of welfare reform: a street-level comparison of employment services in Australia and Denmark', Social Work and Society, 3, 2, $141-57$.

McDonald, C. and Marston, G. (2005) 'Workfare as welfare: governing unemployment in the advanced liberal state', Critical Social Policy, 25, 3, 374-401.

McDonald, C., Marston, G. and Buckley, A. (2003) 'Risk technology in Australia: the role of the job seeker classification instrument in employment services', Critical Social Policy, 23, 4, 498-525.

Mitchell, K. (2006) 'Neoliberal governmentality in the European Union: education, training, and technologies of citizenship', Environment and Planning D: Society and Space, 24, 3, 389-407.

Newman, J. and Tonkens, E. (2011) Responsibility, Participation and Choice: Summoning the Active Citizen in Western Europe, Amsterdam: Amsterdam University Press.

Newman, K. (1999) No Shame in My Game: The Working Poor in the Inner City, New York: Russell Sage.

Rappaport, J. (1985) 'The power of empowerment language', Social Policy, 17, 2, 15-22.

Rawls, J. (1971) A Theory of Justice, Cambridge, MA: Harvard University Press.

Rose, N. (1999) Powers of Freedom: Reframing Political Thought, Cambridge: Cambridge University Press.

SCP (Sociaal en Cultureel Planbureau) (1998) Sociaal en cultureel rapport 1998: 25 jaar sociale verandering, The Hague: SCP.

Sennett, R. (2003) Respect in a World of Inequality, New York: Norton.

Serrano Pascual, A. (2007) 'Activations regimes in Europe: a clustering exercise', in A. Serrano Pascual and L. Magnusson (eds.), Reshaping Welfare States and Activation Regimes in Europe, Brussels: P.I.E. Peter Lang, pp. 275-317.

Soss, J. (1999) 'Welfare application encounters: subordination, satisfaction, and the puzzle of client evaluations', Administration and Society, 31, 1, 50-94. 
Soss, J., Fording, R. and Schram, S. F. (2009) 'Governing the poor: the rise of the neoliberal paternalist state', paper presented at the Annual Meeting of the American Political Science Association, Toronto.

Swierstra, T. and Tonkens, E. (2006) 'Meritocratie en de erosie van zelfrespect', Krisis, 7, 3, 3-23.

Swierstra, T. and Tonkens, E. (2008) De beste de baas? Prestatie, respect en solidariteit in een meritocratie, Amsterdam: Amsterdam University Press.

Van Berkel, R. (2006) 'The decentralisation of social assistance in the Netherlands', International Journal of Sociology and Social Policy, 26, 1, 20-31.

Van de Werfhorst, H. G. and Hofstede, S. (2007) 'Cultural capital or relative risk aversion? Two mechanisms for educational inequality compared', British Journal of Sociology, 58, 3, 391-415.

Walters, W. (2000) Unemployment and Government: Genealogies of the Social, Cambridge: Cambridge University Press.

Warburton, J. and Smith, J. (2003) 'Out of the generosity of your heart: are we creating active citizens through compulsory volunteer programmes for young people in Australia?', Social Policy and Administration, 37, 7, 772-86.

Wieck, A. (1983) 'Issues in overturning a medical model of practice', Social Work, 28, 6, 467-71.

Young, M. (1958) The rise of meritocracy, 1870-2033: an essay on education and equality, London: Thames and Hudson. 